\title{
Leading with Justice: Afterword and Next Steps
}

Beth Wenbourne Hendrick, Doctoral Candidate, California State University, Sacramento

Dr. Vajra Watson, Faculty Director, Doctorate in Educational Leadership, California State University, Sacramento

The term justice has become a catchphrase in education, used often and yet still evasive. In an attempt to define justice in research, policy, and practice, the California State University, Sacramento Doctoral Program in Educational Leadership invited preeminent scholars into the conversation through a public webinar series. Hundreds of people tuned in to listen and learn-some sessions having over 350 active participants. The attendees represented a unique cross-section of stakeholders: about 1/3 from universities, 1/3 from school districts, and 1/3 from community groups. Each webinar began and closed with music (e.g., Ain't No Stoppin' Us Now) that curated and uplifted the virtual space. Local spoken word artists were also invited to share poems that related to the topic. As much as possible, the lessons were experiential and embodied.

\section{We considered the following:}

1. How do we experience justice - not just in thought but in practice?

2. Is it possible to create spaces-even online-that nourish our sense of collective belonging?

3. How do these acts of informed togetherness move us from systems of oppression into ecosystems of equity?

These questions guided our work in the \#LeadingWithJustice webinar series. It's important to note that it's not called Leading toward Justice — which denotes justice as the goal—but in Leading with Justice, emphasizing our walk and how we interact with one another and the world around us. In other words, our goal was to help operationalize justice; moving from the why into the how.

As a way forward, in the subsequent sections, we analyze the recommendations made by each speaker, namely, Professors Richard Milner, Kevin Kumashiro, Gloria Ladson-Billings, and Maureen Gillette, as well as Civil Rights Icon, Dolores Huerta, and Assemblymember, Jose Medina. 


\section{Dr. Richard Milner, Vanderbilt University "SOME STUDENTS WILL SUCCEED BECAUSE OF YOU, AND SOME WILL SUCCEED IN SPITE OF YOU."-MILNER, 2020}

The series began on October 7th with Professor Richard Milner, IV of Vanderbilt University whose book Start Where You Are but Don't Stay There provides school leaders and teachers with the guidance and tools to effectively teach students of color. Dr. Milner's lecture focused primarily on shifting educator mindsets. Students of color can succeed, argued Dr. Milner, when the appropriate mechanisms and structures exist to support them. To successfully create and implement these structures, however, educators must shift our mindsets and conduct our work with focused intentionality. To do this, Dr. Milner recommended four approaches or mindsets. First, he argued for an intentional shift in the language surrounding the achievement gap. It is not sufficient to focus primarily on achievement, argued Dr. Milner, when the reality is that vulnerable students face opportunity gaps created by diminished resources, lack of access to mental health and psychological services, unsafe neighborhoods and overrepresentation in Special Education.

The second mindset educators must adopt is the commitment to be anti-racist in daily practice. The work of educators, argued Dr. Milner, is always about race. Ignoring race, pleading colorblindness or dismissing the racially fraught atmosphere prevalent in American society only prevents educators from developing the strong relationships their students need to thrive. Instead, educators must make conscious efforts to understand their students by engaging in their students' communities. Dr. Milner's third mindset recommendation is to disrupt an entrenched belief system about marginalized students. Instead of focusing on self-esteem, which is simply an effect, educators should focus on developing a sense of self-efficacy in students. Self-efficacy is the student's belief in his or her own ability to complete a task and master a skill. Dr. Milner argued that students must have opportunities to recognize their ability to succeed at something they previously could not. According to Dr. Milner, it is the role of the teacher to "shepherd students into a place of mastery" so that they will be brave enough to try again in the future. Finally, Dr. Milner's fourth mindset involves a new normal wherein excluding students of color is no longer acceptable. Citing research from Sacramento and Boston-area schools, Dr. Milner showed how African American students, though they represent small percentages of the population, are significantly and disproportionately "pushed out" or suspended from classes. These students are often referred for subjective infractions, such as disrespect, whereas their white counterparts are referred for objective infractions, such as tardiness. We must create an educational environment that builds upon the assets of students of color and responds effectively to their realities, needs and powerful academic trajectories.

\section{Delores Huerta, Civil Rights Leader}

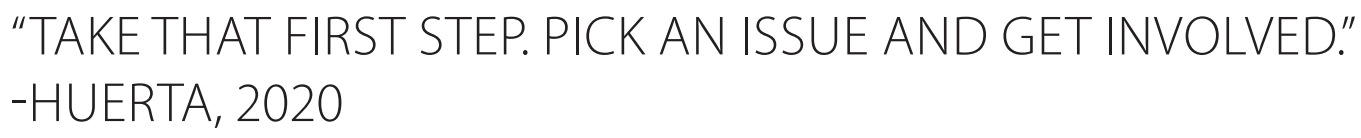

What does it take to become a Civil Rights legend? According to the iconic labor leader, Delores Huerta, it starts with conscientious civic involvement. On October 9th, Ms. Huerta spoke to the Sacramento State community about the importance of organizing and its relationship to transformational leadership. Her presentation, facilitated by the Sacramento State Serna Center, focused on ways young people and future leaders can actively participate in the legislative process as we strive toward equity. Of the many human rights issues covered in her presentation, she focused primarily on ways to improve conditions for women, anti-Black racism, immigrants and first-generation Americans. 
Ms. Huerta's record of community organizing reflects an alternative history of California, as experienced by migrant farmworkers in the San Joaquin Valley. Her efforts, in partnership with Cesar Chavez, created the first labor union representing and protecting these essential workers. Yet, to Ms. Huerta the work is ongoing. Specifically, she appealed to attendees to use their voices in the 2020 election and to ensure that they participated in the 2020 Census. She discussed a variety of propositions on the 2020 ballot that have the potential to improve the lives of disenfranchised populations. These include controversial topics such as affirmative action and rent control. Drawing upon a personal narrative and demographic data from some of California's top universities, she challenged young voters to consider the benefits of affirmative action. She argued that her sons, an attorney and a doctor, were able to attend college in part due to affirmative action laws. She also pointed to the underrepresentation of Black and Latinx students on elite California college campuses. Ms. Huerta also discussed rent control and urged young voters to support equitable access to housing, noting that housing insecurity disproportionately affects Black and Brown citizens.

Ms. Huerta also addressed questions from the Sacramento State community about issues such as the beleaguered Deferred Action for Childhood Arrivals (DACA) immigration policy and ways to combat racism within our communities. Staying true to her message of community involvement, she urged the Sacramento State community to engage in dialogue with those who are at different places in their journey toward understanding. It is our responsibility as leaders, she argued, to help others understand that showing interest in discussing issues of power and privilege does not extinguish racism. It is the act of doing and getting involved that makes the difference.

\section{Assemblymember Jose Medina}

\section{"IT IS IMPORTANT TO TEACH A COMPLEX HISTORY. OTHERWISE, IT IS AN INCOMPLETE HISTORY." -MEDINA, 2020}

As education leaders, it is our responsibility to facilitate truthful dialogue about power and privilege. An important step toward achieving this goal, says California Assemblymember Jose Medina, is to tell an authentic version of history. On October 7th, Assemblymember Medina, who represents California's 61st District, discussed Assembly Bill (AB) 331 which -- if adopted -- would have made Ethnic Studies a graduation requirement for California's nearly two million high school students. Moderated by Dr. Lisa Romero and Sacramento State's Doctorate in Educational Leadership students, Mr. Medina's lecture reflected on the unsuccessful outcome of AB 331 and then offered insight into the future of similar legislation.

Though legislation was adopted in August, 2020 making Ethnic Studies a requirement for California State University students, California Governor Newsom vetoed AB 331 which would have extended this requirement to California's high schools. The governor, though generally supportive of Ethnic Studies legislation, responded to pressure from interest groups who claimed the proposed curriculum was Marxist and anti-Semitic. Specifically, these interest groups took issue with language in the curriculum that was critical of capitalism and alleged human rights violations in Israel. Assemblymember Medina was quick to point out that the curriculum is separate from the legislation, and voiced his concern that this was a lost opportunity for California to push back against what many see as racist rhetoric emanating from the Trump Administration.

Yet, Assemblymember Medina remains optimistic about future legislation requiring Ethnic Studies. After all, he argued, its value cannot be disputed. He argued that when students see themselves reflected in the curriculum, they are much more likely to become engaged with the work and to think critically. The goal of all curriculum, he 
argued, is to teach students to think for themselves and to question assumptions. Ethnic Studies would provide those opportunities because it offers a more authentic version of history, one that reflects the experiences and realities of marginalized communities. He argued that the current curriculum teaches American history as evolving from East to West, which disregards the rich histories of indigenous peoples whose societies thrived in America for centuries before the arrival of European settlers. It also largely excludes the physical and cultural genocide of these people and makes little mention of oppressive laws and practices that methodically perpetuate white supremacy.

Assemblymember Medina urged educators and leaders to support Ethnic Studies because it encourages our students to reflect on their shared and often complex history; to do anything else is to provide an incomplete history. He hopes that through this act of praxis and reflection, we can move our students and society toward a more collective and inclusive understanding of what it means to be an American.

\section{Dr. Kevin Kumashiro, Education Leader "RATTLE CONVENTIONAL WISDOM." -KUMASHIRO, 2020}

Like his esteemed colleagues, Dr. Kevin Kumashiro views education through a lens of possibility. In his lecture on October 14th, Dr. Kumashiro challenged the assumption that schools fail to fulfill their intended purpose. Schools were designed, said Dr. Kumashiro, to "sort and place" students, and they do an excellent job of performing this task they were designed to do. It is for this reason that transformational leaders must look at education systems in a radically new way; we are not simply trying to improve a system for some students. Instead, we must unlearn everything we think we know about the purpose and function of schools. Education is under attack, he argued, but this will always be the case. Education will always be the site of ideological struggle, so it is unacceptable to continue conducting our work as if nothing has changed or needs to change.

To begin this process, Dr. Kumashiro discussed four actions leaders can take. First, education leaders must name the moment and name it in a way that leads to tangible outcomes. Citing Freire, Dr. Kumashiro acknowledged that we must listen to the perspectives of others when identifying solutions to perceived problems. Otherwise, we run the risk of providing answers that do not solve the actual problem. We also must be willing to ask and answer questions about our purpose: what are we doing differently? Why would someone want to work with us? Next, Dr. Kumashiro urged education leaders to dive into contradiction. In fact, he argued, confronting contradiction is the only way leaders can get through to the heart of a problem. Specifically, he discussed the purpose of education, the roles of educators and the ideological struggles we face. Education will always be mired in controversy and so it is insufficient to reframe how we approach one aspect of our work without examining ways to reframe all other aspects. Third, Dr. Kumashiro discussed the process of learning through crisis and resistance. When we reframe our thoughts or approaches, we do not simply learn; we also engage in the process of unlearning. Learning is a fundamentally pedagogical act, and this is uncomfortable, which means we must be willing to address the psychic resistance in ourselves and others that results from the discomfort of changing how we think.

Finally, Dr. Kumashiro called upon education leaders to consider new models for educational systems. Neo-liberal corporate models cannot facilitate change because too often individuals tasked with implementing policies do not share the same ideology as those who create them. Instead, we can look to elements of social movements to create a new framework for change. Social movements work from the ground-up, gain momentum through collective action 
and focus on implementing policies that have long-term, rippling effects. Leadership, said Dr. Kumashiro, is about rattling conventional wisdom; we meet this challenge through collective inquiry.

\section{Dr. Gloria Ladson-Billings, President of the National Academy of Education "IT'S TIME FOR A HARD RESET." -LADSON-BILLINGS, 2020}

Perhaps one way to rattle conventional wisdom is to redefine how we view justice. On October 21st, Dr. Gloria Ladson-Billings, our "Queen Supreme," implored us to reject vague, Western notions of "social justice" and to move toward specificity within equity work. During her lecture, she focused on four key definitions of justice and highlighted how Black people, in particular, face inequities in each of them. To capture an accurate picture of justice within American society, she argued, it is imperative to look at how people live inside it. Dr. Ladson-Billings argued that we should measure justice "by how someone's life goes" which requires ongoing observation, reflection and praxis.

Dr. Ladson-Billings highlighted four ways to view issues of justice and equality in American society. The first is economic justice -- defined as the ability for every citizen to have an income that is stable and adequate to cover their needs. It also means a thriving and growing economy in which every citizen can participate. In our country vast wealth is concentrated among a privileged few, so our society has yet to achieve economic justice. The second form of justice discussed by Dr. Ladson-Billings is criminal justice, which she acknowledged is "broken for Black people." She cited the death of George Floyd and countless other murders of Black citizens by police and the disproportionate incarceration of Black individuals as evidence that, once again, our society falls short on justice. The third form of justice discussed by Dr. Ladson-Billings was environmental justice. Disenfranchised communities are far likelier to live near industrial areas that spew toxic chemicals, and as a result, these populations are disproportionately affected by environmental contaminants. Yet, when legislation mandates improvements, such as planting trees to reduce carbon dioxide, the improvements often happen in wealthier neighborhoods. As a result, our society again fails to provide justice to every citizen. The fourth and final form of justice discussed by Dr. Ladson-Billings was racial justice, which she defined as equitable access to opportunities and resources. In education, these include access to quality teachers and rigorous curriculum and resources that get students into college. Since outcomes can be predicted based solely on a student's zip code, it is clear America has a long way to go before achieving racial justice.

Dr. Ladson-Billings concluded her lecture with the call for a "hard reset" in education. While many educators and citizens long for a "return to normal" she wishes for the opposite. After all, "normal" means students of color are disproportionately suspended from school, failing classes and placed in Special Education. Instead, Dr. Ladson-Billings said we need to recalibrate. Education leaders do this by honestly and candidly discussing economic and social realities with students, and working within our capacity to improve systems. 


\section{Dr. Maureen Gillette, Dean of the College of Education and Human Services at Seton Hall University

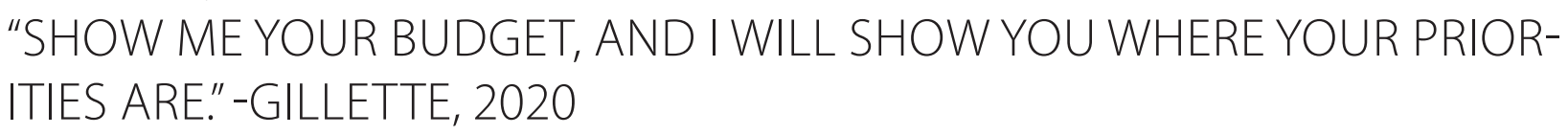

One leader who is unafraid to have candid and honest conversations is Dean Maureen Gillette. Like many of the leaders who shared their wisdom during the Leading with Justice series, Dr. Gillette, who serves as Dean of the College of Education and Human Services at Seton Hall University, expressed the need for urgency in our social justice efforts. The final speaker in the series, Dr. Gillette's lecture on October 28th called on transformational leaders to begin the hard work of organizing to make social justice a reality.

Dean Gillette's track record is evidence that this approach works. Her leadership led to a paradigm shift at Northeastern University, where she served as Dean of the College of Education for over a decade. Her commitment to action led to highly collaborative partnerships with school districts and neighborhood associations in underserved neighborhoods of Chicago. She credits community organizers -- the same people who taught former President Barack Obama to organize -- with providing her the knowledge and means to effect transformational change. One key collaboration created a "Grow Your Own" teacher partnership between Northeastern University and the Logan Square Neighborhood Association in Chicago. Tired of the revolving door of educators and administrators in their local schools, this association suggested preparing neighborhood parents to become educators. The partnership worked to remove barriers by providing childcare, tuition support and transportation to program participants. The community organizers also taught Dr. Gillette how to "speak truth to power" which she used to oppose an extraordinarily high Basic Skills score requirement that disproportionately affected future teachers of color.

From her collaborations with community organizers, Dean Gillette learned several valuable lessons, which she imparted to our community. First, she said transformational leaders must be authentic and transparent. If we cannot be transparent, we must be honest about the reasons we cannot. Next, transformational leaders have to recognize that we pay a price for our actions. Before acting, we must consider what we can and are willing to pay. Finally, we must be careful with our words and actions, always acknowledging that people watch us. It is hard work, she argued, but the work is so important and the payoff is enormous.

Dean Gillette concluded the series with a call to action. Her patience for talking without action has, she said frankly, run out. This sense of urgency translates to a no-nonsense approach to dealing with resistance, and she encouraged other transformational leaders to take the same approach. Insist upon evidence of progress, she argued. Ask to look at budgets; ask to see proof that your organization is committed to doing the hard work associated with shifting paradigms. Only by holding people accountable -- privately or publicly -- will they also begin to feel the urgency necessary to bring about the transformational change our society so desperately needs. 


\section{The Work Continues}

In keeping with the concept that ongoing praxis leads to transformational change, we encourage our community to consider the following:

1. How do you turn now to recognize your sphere of influence and power? And what new actions do you take in the work of racial justice?

2. As we strive to "live our leadership" and "lead with justice" how do our values reverberate throughout our personal, interpersonal and professional lives?

3. What new book will you read? What new forms of knowledge will you explore? How will you stay inspired and connected?

To further engage with us, use the hashtag \#LeadingWithJustice.

All of the webinars are available for viewing at:

https://www.csus.edu/college/education/doctorate-educational-leadership/spotlights/leading-with-justice-speakers.html

As a final note of acknowledgment and gratitude: The series was spearheaded by our program's new director, Dr. Vajra Watson, and included partnerships with the Sacramento State Serna Center and one of our EDD faculty members, Dr. Lisa Romero. The transformational leaders who virtually visited us took time out of their busy schedules to share their insights and we could not have created this space without them. Also, as previously mentioned, we featured community artists from Sacramento Area Youth Speaks; each of them brought to the forefront soul-stirring spoken word performance poetry as an act of radical vulnerability and intergenerational justice. 